\title{
PROBLEMAL ASPECTS OF THE FUNCTIONING OF THE INSTITUTION OF REMOVAL (SELF-REMOVAL) OF A JUDGE IN CIVIL PROCEDURE
}

\section{ПРОБЛЕМНІ АСПЕКТИ ФУНКЦІОНУВАННЯ ІНСТИТУТ ВІДВОДУ (САМОВІДВОДУ) СУДДІ В ЦИВІЛЬНОМУ ПРОЦЕСІ}

\author{
Pernarivska T.P., Candidate of Pedagogical Sciences, \\ Associate Professor at the Department of Modern European Languages \\ Educational and Scientific Institute of Law \\ of University of the State Fiscal Service of Ukraine
}

Yavorska O.M., Applicant for the Second (Master's) Level of Higher Education Educational and Scientific Institute of Law of University of the State Fiscal Service of Ukraine

\begin{abstract}
The article considers the concept of removal (self-removal) of a judge in civil proceedings, analyzes the norms of the Civil Procedure Code of Ukraine on the grounds and procedure for removal (self-removal) of a judge, suggests ways to improve legislation on removal of a judge in civil proceedings. The article mentions international regulations that enshrine a person's right to a fair trial by an independent and impartial tribunal. Scientific definitions of the concepts: "equality", "removal", "self-removal" are given. The legislative bases on the basis of which the trial is carried out, and which judges are guided by when deciding procedural applications for dismissal of a judge, are considered. The grounds for dismissal of a judge and the grounds on which a judge must resign are analyzed. The authors emphasize the reasons and preconditions for the abuse of procedural rights by participants in civil proceedings. The provisions of the laws of Ukraine concerning the administration of justice are analyzed in detail. Judicial practice on the removal of a judge in civil proceedings is also analyzed and the peculiarities of the legal regulation of the removal of a judge are noted. The authors propose to amend some provisions of civil law, in particular those governing the removal and self-removal of a judge. The article contains information on judicial practice on issues of dismissal, in particular, examples of decisions of judges concerning the satisfaction or refusal to satisfy applications for dismissal of a judge. The most common grounds on the basis of which judges refuse to grant an application for recusal are indicated, as well as the procedure for consideration by the court of applications for recusal received from participants in civil proceedings, as well as applications for recusal.
\end{abstract}

Key words: removal, self-removal of a judge, justice, impartiality of court, independence of court, equality, legality, powers of a judge.

У статті розглянуто поняття відводу (самовідводу) судді в цивільному процесі, проаналізовано норми Цивільного процесуального кодексу України щодо підстав та порядку відводу (самовідводу) судді, запропоновано шляхи вдосконалення законодавчої регламентації питань, що стосуються відводу судді в цивільному процесі. У статті згадано про міжнародні нормативно-правові акти, які закріплюють право особи на справедливий розгляд справи незалежним та неупередженим судом. Наведено наукові визначення понять «рівність», «відвід», «самовідвід». Розглянуто законодавчі засади, на основі яких здійснюється судовий розгляд та якими керуються судді під час вирішення процесуальних заяв про відвід судді. Проаналізовано підстави відводу судді та підстави, за яких суддя повинен заявити про самовідвід. Автори акцентують увагу на причинах та передумовах зловживання процесуальними правами 3 боку учасників цивільного процесу. Детально проаналізовано положення законів України, які стосуються здійснення правосуддя. Також проаналізовано судову практику з питань відводу судді в цивільному процесі та вказано на особливості правового регулювання відводу судді. Автори пропонують внести зміни до деяких положень цивільного законодавства, зокрема тих, що регулюють питання відводу і самовідводу судді. Стаття містить інформацію щодо судової практики з питань відводу, зокрема наведено приклади рішень суддів, які стосуються задоволення чи відмови в задоволенні заяв відводу судді. Окреслено найпоширеніші підстави, на основі яких судді відмовляють у задоволенні заяви про відвід, а також описано процедуру розгляду судом заяв про відводи, які надходять від учасників цивільного процесу, і заяв про самовідводи.

Ключові слова: відвід (самовідвід) судді, правосуддя, неупередженість суду, незалежність суду, рівність, законність, повноваження судді.

Today, the issue of an independent and impartial court is extremely important. After all, practically every normative legal act adopted by the legislative body of Ukraine enshrines the principle of the rule of law and the principle of legality, as well as the fact that everyone has the right to a fair trial by an independent and impartial court. It should be emphasized that not only the national domestic legislation of Ukraine contains such provisions. There are almost identical provisions in international legal acts that Ukraine has ratified or acceded to, thus recognizing these acts as national laws. So, this topic is extremely relevant.

Many scientists and scholars have dealt with the issue of disqualification of a judge, in particular: S.F. Demchenko, Ya.P. Zeikan, O.M. Babych, D.D. Luspenyk, Yu.D. Prityka, S.Ya. Fursa, M.M. Yasynok, V.V. Petryk and others.

The purpose of the article is a comprehensive analysis of the civil law of Ukraine, which contains the main aspects of the functioning of the institution of removal of a judge, as well as the identification of the main theoretical and practical problems of consideration of applications concerning the removal of a judge.

The tasks we set ourselves to achieve our goal:
- to analyze the scientific doctrine and legislation containing the definition of the concept of "self-removal", "removal", "equality", "grounds for the judge's dismissal";

- to investigate the procedure for exercising the right of a judge to be removed by the participants of a civil process;

- to consider the problems that arise in practice when declared taps.

According to Article 6 of the European Convention on Human Rights: "Everyone has the right to a fair and open trial by an independent and impartial tribunal..." $[1$, p. 9].

"The independence of the courts is a prerogative, not for the benefit of the judges alone, but for the benefit of the rule of law and for those who rely on justice", the European Judicial Advisory Council found [2].

The modern understanding of the meaning of the concept of "equality" is quite simple: the same position of people in society; without taking into account any privileged position and status - regarding legal equality. The idea of equality was enshrined in law in the form of art. 1, the Universal Declaration of human rights of 1948: "All human beings are born free and equal in dignity and rights". Accordingly, the Basic Law of Ukraine also contains articles that enshrine the category 
of equality in the administration of justice - articles $21,24,26$, 129 of the Constitution of Ukraine [3].

According to article 2, part 3, paragraph 2 of the Civil Procedure Code of Ukraine, justice must be administered on the basis of respect for honor and dignity, equality of all participants in the trial before the law and the court [4].

The civil legislation of Ukraine provides for the possibility for each participant in civil proceedings to declare the dismissal of such a judge if there are the necessary grounds and facts that indicate the impartiality of a judge. However, there is no interpretation of the term "removal of a judge" in the Civil Procedure Code of Ukraine. In legal doctrine, this concept is defined as "removal (removal) of a judge, which can be carried out both independently by the judge and at the will of the parties involved in the case, from consideration of a particular case in accordance with existing grounds established by law" [5, p. 293].

The grounds for the removal of a judge include:

1) the judge is a family member or close relative of the party or other participants in the proceedings;

2 ) the judge participated in the case as a witness, expert, specialist, translator, representative, lawyer, court clerk or provided legal assistance to a party or other participants in the case in this or that case;

3 ) the judge is directly or indirectly interested in the case;

4) the procedure for appointing a judge to hear the case was violated

5) there are other circumstances that cast doubt on the impartiality or objectivity of the judge [4].

Since paragraph 5 , part 1 of article 36 (other circumstances), each party to the trial may interpret in their own way and in their favor, for example in order to delay the trial in court, as to refute or refuse the so-called "absurd" taps, also a certain period of time is allotted. Therefore, we propose to either specify or replace the provisions on other circumstances that cast doubt on the impartiality or objectivity of the judge.

It is another matter when the removal of a judge is lawful and confirmed by facts. In this case, the judge who was challenged had to resign from the moment when he directly or indirectly became interested in resolving the case in favor of a particular party, so as not to violate the law and the principle of respect for honor and dignity of the participants and their equality before the law and the courts. For example: the plaintiff is a good acquaintance of the judge, and the judge, knowing this, does not self-removal, because he is interested in satisfying the plaintiff's claims. Accordingly, there is no equality of participants in the trial in this case.

We must also mention the principle of the rule of law, which must be applied absolutely and fully in the judiciary. The Constitutional Court of Ukraine has aptly expressed its position in this decision, in particular, that the principle of the rule of law - is the rule of law in society. It must be embodied in law-making and law-enforcement activities, including laws that contain ideas of justice, freedom and equality [6].

Of course, justice is a guarantee of protection of human rights and freedoms, which is realized in accordance with the principles of the rule of law. It should be noted that the independence of the judiciary is not a prerogative or privilege granted to judges to satisfy their own interests. The independence of the judiciary is granted solely in the interests of the rule of law and those who have recourse to impartial justice. So, judges should not abuse this. The Law of Ukraine "On the Judiciary and the Status of Judges" defines the basic principles of the organization of the judiciary, including the rules relating to the mechanism of removal of a judge. For example: article 1 -judicial power is exercised by independent and impartial courts; article 6 - in the administration of justice, the courts are independent of any unlawful influence. Courts administer justice on the basis of the Constitution and laws of Ukraine and on the basis of the rule of law; article 8 - the judge shall consider cases received in accordance with the procedure for the distribution of court cases established in accordance with the law. The distribution of court cases between judges may not be influenced by the wishes of the judge or any other person; article 9 - equality before the law and the courts. The Law also directly determines the legal status of a judge, in particular the requirements of incompatibility (article 54), as well as the judge's obligation to hear the case impartially, to observe the judge's oath (article 56) [7].

As mentioned earlier, the concept of removal is not defined in the Civil Procedure Code of Ukraine, the same problem with self-removal. The definition of self-removal is given by scientists. For example, D.D. Luspenyk notes that selfremoval is the duty of the court, and the statement of recusal is the right of persons involved in the case [8, p. 78]. The right opinion of M.M. Yasynok deserves attention. She believes that self-removal is not a way to evade judges from considering scandalous or complex cases - it is one of the civilized solutions that help to avoid contradictions between the interests of individuals in the court and legal human rights [9, p. 50].

It should be emphasized that a judge is obliged to resign if there are grounds specified in articles 36, 37 and 38 of the Civil Procedure Code of Ukraine. If the removal of a judge, is filed by the parties, it must be motivated and declared within ten days from the date of receipt by the party of the decision to open proceedings, but not later than the beginning of the preparatory hearing or the first hearing, if the case is considered in summary proceedings. The self-removal may be declared no later than the beginning of the preparatory hearing or the first court hearing, if the case is considered in summary proceedings. If the specified term has expired, it is allowed to declare removal (self-removal) only in exceptional cases when the grounds for removal (self-removal) could not be known to the applicant before the expiration of the specified term, but not later than two days from the day when the applicant learned about such grounds [4].

Also in the Civil Procedure Code of Ukraine specified in article 40 , that the issue of dismissal of a judge is decided by the court hearing the case. The court may satisfy the removal only when it concludes that such removal is justified. That is, a particular judge must recognize the fact that he is impartial, that there are real grounds for his removal, that he did not resign, although he should have done so, according to the civil law of Ukraine, and accordingly satisfy his resignation. We consider it necessary to change this provision, because in practice the procedure of consideration and satisfaction of the removal of a judge is extremely difficult to implement. First, it is difficult for a judge to remain impartial when considering an application his removal. Second, the subjective attitude of the participants in the case towards a particular judge, who accordingly did not satisfy the application for the removal, also changes in a negative direction.

Our analysis of judicial practice gives grounds to assert that there are almost no positive court decisions on the removal of a judge. For example, in order to prove that a judge is not impartial or independent, or in any way interested in resolving a case in favor of a particular party, it is necessary to substantiate the existence of circumstances that may indicate possible bias. "The circumstances that formed the basis of the application for removal must be proven. The removal must be motivated. If he is not motivated, this is a reason to refuse to satisfy him". On this basis, the judge of the Shpola district court of Cherkasy region refused to satisfy the recusal of the presiding judge [10].

Moreover, the court may leave the application without motion if it finds in it signs of abuse of the right to removal in order to delay the proceedings. This abuse is manifested in the application of repeated recusals to judges who are considering applications for recusal to another judge. This conclusion was reached by a judge of the Kovpakivsky district court of Sumy [11].

Another important fact that proves that it is difficult for the participants in the trial to prove (even if there is evidence 
and grounds) the validity of the judge's removal, is the decision of the judge of the Sviatoshynskyi district court of Kyiv. The plaintiff challenged the judge. In his decision, the judge stated that the removal must be motivated and stated within ten days from the date of receipt of the party's decision to open proceedings, but not later than the beginning of the preparatory hearing or the first hearing, if the case is considered in summary proceedings. After the expiration of the specified term, it is allowed to apply for recusal only in exceptional cases, when the grounds for recusal could not be known to the applicant before the expiration of the specified term. That is, as established by the legislator, such a ground for the removal already existed at the time the proceedings were opened, but was not known to the applicant. The applicant (plaintiff) claims that the judge who ruled to leave the statement of claim without motion and to return the statement of claim is impartial, and also stated that his decisions are unfounded. However, the judge noted that among the grounds for disqualification of a judge, there is no such reason as "impartiality" of a judge. And if we are talking about the bias of the judge, it still needs to be proved, and the applicant has no evidence [12].

Based on the analysis of case law, applications for selfremoval are extremely rare, but are always subject to satisfaction, as they are considered by the judge who himself declares this recusal. So, the Judgment of the Judge of the Romensky city district court of the Sumy region considered and satisfied the application for self- removal of the judge, on the grounds that she is a judge of the Romensky city district court of the Sumy region, who is the defendant in the case [13].

In accordance with paragraph 1 of article 6 of the Convention for the Protection of Human Rights and Fundamental Freedoms: "Everyone has the right to a fair and public hearing within a reasonable time by an independent and impartial tribunal established by law, which shall settle disputes concerning his civil rights and obligations" [1]. However, in exercising their right to a fair, impartial, objective and independent court, by removal a judge, litigants are often denied. This once again confirms the inaccuracies and gaps in Ukraine's civil law that need to be addressed immediately in order for Ukraine's judicial system to function at least as it should.

Thus, the institution of the removal of a judge is an important tool and guarantee in the system of protection of rights, freedoms and interests of man and citizen in the administration of justice. However, given the essential aspects of the legal regulation of the procedure of removal (self-removal) of a judge, enshrined in the Civil Procedure Code of Ukraine, this institution may become to some extent an abuse of rights by the judge. To prevent this, we consider it necessary first of all to enshrine in the Civil Procedure Code of Ukraine the concepts of "removal", "self-removal" of a judge, change the rules on consideration of the removal by a judge who is challenged, and regulate in detail the grounds for removal of a judge to prevent abuse of procedural rights, civil proceedings.

\section{BIBLIOGRAPHY}

1. Конвенція про захист прав людини та основоположних свобод: Закон України від 17.07.1997 р. № 475/97. Відомості Верховної Ради України. 1997 р. Ст. 59 (із змінами).

2. Висновок N 1 (2001) Консультативної ради європейських суддів для Комітету міністрів Ради Європи про стандарти незалежності судових органів та незмінюваність : Закон України від 01.01.2001 р. № 1 (2001). Відомості Верховної Ради України. 2001 р.

3. Конституція України : Закон України від 28.06.1996 р. № 2680-VIII. Відомості Верховної Ради України. 1996 р. № 30. Ст. 141 (із змінами).

4. ЦИвільний процесуальний кодекс України: Закон України від 18.03.2004 р. № 1618-IV. Відомості Верховної Ради України. 2004 р. № 40-41, 42. Ст. 492 (із змінами).

5. Бабич О.М. Відвід судді в цивільному процесі. Сучасна цивілістика: матеріали 9-ої Міжнар. наук. конф. студентів, аспірантів та молодих вчених. Одеса. 2014. 516 с.

6. Рішення Конституційного Суду України від 02.11.2004 p. № 15-рп/2004. URL: https://zakon.rada.gov.ua/laws/show/v015p710-04.

7. Про судоустрій і статус судді в: Закон України від 02.06.2016 № 1402-VIII. Відомості Верховної Ради України. 2016 р. № 31. Ст. 165 (зі змінами).

8. Луспеник Д.Д. Розгляд цивільних справ судом першої інстанції. Харків: Харків юрид. 2006. 480 с.

9. Ясинок М.М. Інститут відводу - яким йому бути. Бюлетень М-ва юстиції, 2006. № 6. С. 46-51.

10. Ухвала Шполянського районного суду Черкаської області від 11 грудня 2015 року по справі № 710/1797/15-ц (про стягнення вартості безпідставно набутого майна). Єдиний державний реєстр судових рішень. URL: http://reyestr.court.gov.ua/Review/54990745.

11. Ухвала Ковпаківського районного суду м. Суми від 31 липня 2019 року по справі № 578/1096/14-к. Єдиний державний реєстр судових рішень. URL: http://reyestr.court.gov.ua/Review/83346787.

12. Ухвала Святошинського районного суду м. Києва від 6 листопада 2019 року по справі № 759/1314/19. Єдиний державний реєстр судових рішень. URL: http://reyestr.court.gov.ua/Review/85443787.

13. Ухвала Роменського міського районного суду Сумської області від 7 листопада 2019 року по справі № 585/4221/19. Єдиний державний реєстр судових рішень. URL: http://reyestr.court.gov.ua/Review/85450798. 